\title{
DO GROTESCO: ETIMOLOGIA E CONCEITUAÇÃO ESTÉTICA
}

\section{FROM THE GROTESQUE: ETYMOLOGY AND AESTHETIC CONCEPTUALIZATION}

\begin{abstract}
Fernanda Lima (UFRJ/CAPES) ${ }^{1}$
Resumo: O presente artigo objetiva depreender a estrutura da estética grotesca, abordando-a sob uma dupla perspectiva: uma perspectiva genealógica, que dará conta dos fatores linguísticos e extralinguísticos que determinaram a primeira conceituação do grotesco, num momento histórico preciso, e uma perspectiva que compreenderá a trajetória do conceito, sua gradativa expansão no campo artístico, destacando as diferentes significações que lhe foram atribuídas ao longo dos séculos, até a sua configuração como um vasto e complexo domínio conceitual. Entretanto, devese ressaltar que neste trabalho, a análise da expansão conceitual do grotesco limita-se ao espaço de tempo que abrange a época do surgimento do conceito até o advento do romantismo francês. As épocas de efervescência ou latência do conceito serão assinaladas, assim como seus diferentes percursos, em vários países, apontando também as circunstâncias que conduziram à sua cisão em duas noções distintas: uma trágica e outra cômica.
\end{abstract}

Palavras-chave: Estética grotesca; etimologia; romantismo francês.

Abstract: This article aims to infer the structure of the grotesque aesthetics approaching it under a dual perspective: a genealogical perspective which will deal with linguistic and extralinguistic factors who determined the first conceptualization of the grotesque at a precise historical moment and another perspective which will cover the trajectory of the concept, its gradual expansion in the artistic field, highlighting the different meanings assigned to it over the centuries until its configuration as a vast and complex conceptual domain. However, it should be noted that in this study, the analysis of the conceptual expansion of the grotesque is limited to the time gap covering the moment of the emergence of the concept until the advent of French Romanticism. The ages of effervescence or latency of the concept will be marked as well as their different paths through several countries pointing out also the circumstances that led to its split into two distinct notions: one tragic and other comic.

Keywords: Aesthetics grotesque; etymology; French Romanticism.

\section{A etimologia do termo grotesco}

Segundo a lógica do senso comum, o termo grotesco é utilizado como sinônimo de bizarro, escatológico, extravagante ou cômico. Tal fato indica o desconhecimento, inclusive dos estudantes de literatura, da significação problemática do conceito, que denota um estranho e vasto campo estético, caracterizado por ultrapassar os limites da representação, exacerbando a dimensão dionisíaca da criação artística.

\footnotetext{
${ }^{1}$ Pós-doutoranda da Universidade Federal do Rio de Janeiro. Contato: nandalima@ig.com.br
} 


\section{Revista InterteXto / ISSN: 1981-0601}

v. 9 , n. 1 (2016)

Derivado de grotta, o termo grotesco designa, etimologicamente, certo tipo de decoração ornamental encontrado em grutas da Itália, no decurso de escavações arqueológicas, em fins do século XV. Esta ornamêntica era composta por desenhos, pinturas e esculturas que ilustravam a mistura dos reinos animal, vegetal e mineral. Esta combinação deu origem a formas que, por romperem com o ideal clássico de arte (mimesis do real, verossimilhança), foram classificadas hostilmente como quiméricas, irreais, monstruosas e até mesmo diabólicas. Assim, a descoberta de um novo tipo ornamental constitui o fator extralinguístico que motivou a conceituação do grotesco, termo formado pelo acréscimo do sufixo -esco, indicando proveniência, à palavra grotta. Esta definição de ordem genealógica pode ser encontrada em dicionários e também foi adotada por Wolfgang Kayser, no livro O grotesco (2003, primeira edição datada de 1957), uma das principais referências acerca do tema. Este, porém, ressalta que o fenômeno artístico é mais antigo do que o seu nome e que uma história completa da estética grotesca "deveria compreender a arte chinesa, etrusca, asteca, germânica antiga e outras mais, do mesmo modo que a literatura grega [...] e outras manifestações poéticas" (KAYSER, 2003, p. 17). Apesar da existência de manifestações artísticas características do grotesco em épocas anteriores à descoberta do século XV, o que é relevante para a análise etimológica, como a de Kayser, é o contexto do estabelecimento do conceito. O procedimento do teórico em sua análise da genealogia do grotesco indica a qualidade de seu trabalho, pois como afirma Henrique Cairus, em seu artigo Etimologias (2004), uma boa análise etimológica deveria se desenrolar como uma "história dos étimos" e não como uma lição de semântica. Desta forma, a verdadeira etimologia deveria "[...] auxiliar o historiador da língua a localizar o texto e o contexto de um momento de um determinado uso de um determinado étimo. [...] os verdadeiros etimólogos deveriam também ser autênticos historiadores dos conceitos" (CAIRUS, 2004).

Para que se compreenda o que possa realmente vir a ser um conceito e em que consiste uma história dos conceitos, esta afirmação do professor Henrique Cairus será relacionada à teoria de Reinhart Koselleck. No texto Uma história dos conceitos (1992), Koselleck instaura, inicialmente, uma distinção entre "palavras teorizáveis" (conceitos) e "palavras em si mesmas reflexivas". As primeiras surgiriam a partir de uma nova experiência histórica, de um referencial histórico desconhecido que mobilizaria os falantes de determinada língua a nomeá-lo, pondo em questão o próprio léxico desta língua. Com 


\section{Revista InterteXto / ISSN: 1981-0601 \\ v. 9, n. 1 (2016)}

o tempo, o conceito adquire abstração, tornando-se passível de teorização. Considerando-se o estranhamento provocado pela descoberta de um novo tipo ornamental, no final do século $\mathrm{XV}$, verifica-se a pertinência do termo grotesco à categoria de "palavras teorizáveis".

Koselleck também defende a ideia de que todo conceito seria, ao mesmo tempo, Fato e Indicador, logo que "[...] todo conceito é não apenas efetivo enquanto fenômeno linguístico; ele é também imediatamente indicativo de algo que se situa para além da língua" (KOSELLECK, 1992, p. 136). Novamente deve-se assinalar a propriedade da análise etimológica do grotesco empreendida por Wolfgang Kayser, visto que ele dá conta da raiz linguística do vocábulo (formado pelo acréscimo do sufixo -esco, indicando proveniência, à palavra grotta), assim como do fator extralinguístico que motivou sua conceituação. O estudo de Kayser denota os princípios da historiografia alemã, que compreende a história como uma epistemologia empírica, ou seja, um conhecimento fundado na experiência, e não um mero fenômeno de linguagem. Finda esta primeira etapa, onde a genealogia e a primeira conceituação do grotesco foram examinadas, será iniciada a análise da expansão do conceito ao longo do tempo, em diferentes países e modalidades artísticas.

\section{O grotesco e sua trajetória}

Após sua impactante descoberta, constata-se uma ampla difusão do grotesco, no século XVI, em vários países da Europa. Ao definir a cultura deste século, Michel Jeanneret destaca que "a regressão às formas primordiais, o desejo de captar, antes de qualquer fixação, a livre eclosão das forças originárias estão inscritos no centro do naturalismo do Renascimento" (JEANNERET, sd, p. 124, tradução nossa). O transformismo da matéria, os mitos da metamorfose que remontam a Ovídio, a natureza amorfa, flexível e instável do mundo primitivo (caos original) são noções que orientam as produções artísticas e científicas do século XVI e que, ao mesmo tempo, justificam a expansão e a atração pela estética grotesca neste momento histórico.

Esta concepção de mundo que privilegia a natureza híbrida e informe dos corpos, fundamentada na crença da mutação que anima a matéria, acaba por admitir as formas monstruosas como manifestações exuberantes da força criadora. As aberrações morfológicas constam na documentação da época como descrições de crianças 


\section{Revista InterteXto / ISSN: 1981-0601 \\ v. 9 , n. 1 (2016)}

siamesas, hermafroditas, bebês peludos (lobisomens) ou com traços animalescos, gigantes, ciclopes, animais mutantes (peixes com patas, unicórnios, cinocéfalos), escritas por anatomistas, cirurgiões, padres e navegadores. A escola dos humanistas elaborou uma versão otimista ante a singularidade destes monstros, sustentando que tais anomalias representavam a prova concreta da energia inesgotável e múltipla da natureza. Diante da riqueza da documentação e da fortuna dos monstros entre humanistas e iletrados, a Igreja também constrói uma interpretação positiva de tais anomalias, que revelariam a grandiosidade do poder do Criador, capaz de criar um número infinito de seres, segundo uma lógica que a razão humana não alcança, fazendo emergir a ignorância e as limitações dos homens diante da complexidade das criações monstruosas.

Impulsionado por tais idéias do século do Renascimento, o grotesco se desenvolve no campo do desenho, da pintura, da gravura, da tapeçaria e da escultura, sendo definido como arte ornamental de cunho fantasioso, recebendo também a qualificação de "sonho de pintores" (sogni dei pittori). Vários artistas italianos da Renascença deram vida a ornamentos grotescos, entre estes, uns dos mais conhecidos e interessantes foram aqueles criados por Rafael, por volta de 1515, para decorar as pilastras das loggie papais. A descrição de tais ornamentos é fornecida por Wolfgang Kayser:

[...] gavinhas que se enroscam e se desenroscam, e de cuja folhagem brotam por toda parte animais (de modo que pareçam suspensas as diferenças entre plantas e animais); delicadas linhas verticais nas paredes laterais, que têm de suportar ora uma máscara, ora um candelabro, ora um templo (de tal maneira que o princípio da estática é levado ao absurdo). [...] (2003, p. 18)

Nesta ruptura com relação às ordens da natureza está presente o componente lúdico, alegre e onírico do grotesco, mas também algo de sinistro e angustiante, na representação de um mundo diferente ou distorcido. Leonardo da Vinci, outro grande nome da época, num desenho intitulado Cabeça grotesca (1504-1507), põe em questão, por sua vez, a separação incisiva entre as diferentes espécies, dotando uma face humana de traços animalescos, traduzindo o hibridismo peculiar ao grotesco.

No final do século XVI, manifesta-se, na Itália, um forte interesse com relação ao cenário de grutas e subterrâneos. A pedido dos nobres, artistas como Giorgio Vasari, Bernardo Buontalenti e Jean Bologne, se dedicam à construção e ornamentação de grutas artificiais, como aquelas que se encontram no Jardim de Boboli (Grotta Grande, 


\section{Revista InterteXto / ISSN: 1981-0601}

v. 9 , n. 1 (2016)

Grotticina di Madama), com desenhos, pinturas e esculturas de animais, deuses e máscaras antropomorfas. Percebe-se que, no imaginário desta época, a gruta está associada a uma sorte de caos primitivo, fundador, de natureza próspera, designando uma espécie de espetáculo das origens, uma mise en scène da geração da natureza mineral.

Deve-se ressaltar a utilização de formas grotescas e monstruosas, durante a primeira metade do século XVI, enquanto armas dentro do movimento iniciado, na Alemanha, por Lutero. Este, rebelando-se contra a ostentação e a corrupção instaladas no seio do Vaticano e irradiadas na conduta do clero de forma generalizada, propõe uma reforma radical dos dogmas da Igreja católica, formulando novos princípios que deveriam orientar a conduta dos sacerdotes e dos fiéis. Lutero denuncia os abusos do Papa em panfletos e libelos difamatórios que fazem sucesso em vários países da Europa entre artistas, religiosos reformistas, escandalizando também o povo. Tais panfletos eram ilustrados com desenhos ou gravuras atribuídos a Lutero, onde o Papa, assumindo o papel de anticristo, é representado de forma híbrida, numa mistura de homem e diabo, homem e besta ou como um verdadeiro monstro. Para representar o soberano da Igreja católica sob uma forma grotesca, Lutero seleciona algumas das aberrações que compunham o repertório de imagens monstruosas difundido no século XVI e que já faziam parte das superstições populares. Thomas Wright reproduz duas gravuras do gênero, célebres no tempo da Reforma Protestante e consideradas como expressão suprema da caricatura satírica: o Papa-asno e o Monge-bezerro. Estas ilustrações datam do ano de 1545, contando sempre, nas várias publicações, "com um texto explicativo, atribuído a Lutero ou a Mélanchthon, texto que as apresentava como emblemas do papado e dos abusos da Igreja romana e, naturalmente, como um prognóstico da proximidade da condenação e queda desta última" (WRIGHT, 1875, p. 230, tradução nossa).

$\mathrm{Na}$ França, Calvino figurava como o maior defensor dos ideais da Reforma Protestante, apesar de contar com conduta e temperamento profundamente distintos daqueles manifestados pelo reformista alemão, como sublinha T. Wright: "Calvino abraçou doutrinas e formas de governo eclesiástico que um luterano não gostaria de admitir. [...] os calvinistas [...] nos deixaram poucas caricaturas ou gravuras burlescas de qualquer sorte" (1875, p. 238). Desta forma, a diferença entre o radicalismo da reforma luterana e o tom sóbrio e moralista daquela sustentada por Calvino pode constituir um 


\section{Revista InterteXto / ISSN: 1981-0601 \\ v. 9 , n. 1 (2016)}

fator relevante com relação às diferentes interpretações do grotesco elaboradas, posteriormente, na Alemanha e na França. O desequilíbrio quanto ao grau de controle ou censura de que dispunha a Igreja nestes dois países, acarretará na ramificação da estética grotesca em uma vertente trágica e outra cômica, como será explicitado mais adiante.

François Rabelais aparece como outro importante representante do grotesco neste século. Em meio ao conflito entre papismo e protestantismo, Rabelais exalta o epicurismo, doutrina que proclama a busca do prazer, através dos personagens Gargantua e Pantagruel. Na obra de Rabelais esta busca do prazer se associa a banquetes e à natureza libertária das festas populares, criando um circuito hiperbólico de apetite desmedido e de dilatação dos corpos. Assim, além da estatura colossal, os personagens também são caracterizados pela hipertrofia de narizes, barrigas e corcundas, seguindo o princípio de flexibilidade anatômica dos corpos. Esta representação do grotesco acaba por atingir o plano do grotesco erótico, por meio de cenas de orgia e da linguagem vulgar, referente aos órgãos genitais, e do grotesco nauseabundo, relativo a todas as sortes de excrementos e secreções dos corpos, instaurando, assim, uma relação entre grotesco e rebaixamento dos temas literários.

Na segunda metade do século XVI, a política moralizante da Contra-Reforma e a revalorização das regras da arte clássica preconizadas por Aristóteles, constituem instrumentos eficazes de neutralização e desqualificação da estética grotesca. Considerando-se o princípio da mimesis aristotélica, a arte grotesca, de origem enigmática e primitiva, é classificada como representação de um mundo anterior à lógica ocidental e à era cristã, logo, incompatível com a cultura e a moral européia da época, devendo ser banida do campo das artes e, principalmente, dos projetos de ornamentação das igrejas. Posteriormente, através da exploração da etimologia do conceito, o grotesco é condenado pela Igreja como manifestação do demônio. Os religiosos afirmavam que o espaço de grutas e subterrâneos, onde fora encontrada a ornamêntica grotesca, constituía um lugar propício para as manifestações de forças nefastas e diabólicas, pois nestes lugares, desde a Idade Média, se realizavam cultos e sacrifícios ao demônio. Todavia, esta declaração do clero parece ter provocado efeito oposto, visto que a atração pelo desconhecido e pelo proibido acarretou na crescente marcha do grotesco. Tal fato ilustra a afirmação de Georges Bataille de que "o interdito atribui ao que ele condena um sentido que em si mesma a ação proibida não tinha. O interdito induz à transgressão, sem 


\section{Revista InterteXto / ISSN: 1981-0601}

v. 9 , n. 1 (2016)

a qual a ação não teria a aparência perigosa que seduz... É a transgressão do interdito que fascina..." (BATAILLE, 1971, p. 91-92, tradução nossa).

Ainda no século XVI, Montaigne translada o conceito de grotesco do domínio das artes plásticas para o da literatura, quando classifica os seus próprios Essays como grotescos, assemelhando-os a corpos monstruosos, sem proporção nem ordem. Assim, Montaigne dota o vocábulo de certa abstração, transformando-o em conceito estilístico. Esta nova utilização do termo grotesco pelo ensaísta constituiu um dos fatores capitais para que, no século XVII, os artistas franceses empregassem o termo como adjetivo, logo com um sentido mais amplo. Vale ressaltar que os adjetivos representam um problema para as línguas, visto que por suas propriedades de valorização e interpretação, se distanciam do vínculo com o objeto concreto. Desta forma, o grotesco deixou de denotar, exclusivamente, um tipo de ornamento com características daqueles encontrados nas grutas italianas, no fim do século XV. Os dicionários franceses do século XVII já fornecem um sentido figurado da palavra grotesco que poderia significar ridículo, bizarro, extravagante, bufão, como mostra Wolfgang Kayser, neste fragmento: "No dicionário da Academia (1694 e outros anos), aparece a seguinte entrada: '[...] fig. Ridicule, bizarre, extravagant. [...] Eis uma citação do Dictionnaire français, de Richelet, Amsterdam, 1680: Grotesque, adj. Plaisant, qui a quelque chose de plaisamment ridicule. [...]" (2003, p. 26). Naquele período, constata-se certo enfraquecimento do traço de temibilidade do grotesco que, associado ao cômico e ao burlesco, provocaria apenas o riso despreocupado.

Esta interpretação inocente e lúdica que o conceito adquire no século XVII francês parece surgir de uma vinculação do grotesco ao estilo satírico de Jacques Callot, que parte para Florença, ainda muito jovem, para se especializar em técnicas de ilustração e de gravura. Mergulhado na cultura das mascaradas italianas, Callot torna-se um dos mais geniais e famosos ilustradores da Commedia dell'arte. Este gênero teatral popular surge na Itália, em meados do século XVI, caracterizando-se por inovações estéticas como os tipos fixos (personagens estereotipados, invariáveis, logo, facilmente identificados pelo público), a intervenção das atrizes em cena, dispositivos cênicos mecânicos, o uso de máscaras maleáveis e que cobriam apenas a parte superior do rosto do ator, o improviso, possibilitado por um roteiro relativamente livre (uma espécie de canevas) e a ênfase à expressão corporal, que contava com piruetas, mímicas, movimentos ágeis e precisos. Bernard Jolibert salienta a significação da palavra "arte" na língua italiana da época, designando habilidade técnica ou profissão, desta forma, a Commedia dell'arte 


\section{Revista InterteXto / ISSN: 1981-0601 \\ v. 9 , n. 1 (2016)}

corresponde a "uma industrialização do teatro, com formação de companhias por meio de contratos e estatutos, com mestres e aprendizes, [...] com prática itinerante desta indústria de um povoado a outro" (JOLIBERT, 1999, p. 6, tradução nossa). Nas ilustrações da Commedia dell'arte, criadas por Jacques Callot, os personagens são paramentados de máscaras com narizes embicados, queixo pontiagudo, cabeça alongada, penas enormes, excrescências morcegais, cristas de galo, passando a idéia de metamorfose ou de uma fusão do humano com o animalesco ${ }^{2}$. Estas caricaturas de Callot abriram um novo domínio para o grotesco, sendo extremamente significativas para a história do conceito.

A atração pela figura do demônio atravessa o século XVI e se manifesta de forma acentuada no século XVII, levando os artistas a buscarem as origens desta demonologia para fundamentar suas composições. Remonta-se, então, aos desertos do Egito, às referências bíblicas que apontam para Santo Antão e suas tentações. Assim, traduzindo as angústias e o gosto da época, Jacques Callot representou por duas vezes a Tentação de Santo Antão (a primeira entre 1616-1617, e a segunda em 1635), dando vida a seres grotescos, monstruosos e infernais. Esta obra de Callot, juntamente com a série de Caprichos (1616/1617) e Petites et Grandes Misères de la Guerre (1633) constituem suas produções artísticas mais sérias e aterradoras.

$\mathrm{Na}$ França do século XVII, também se constata a presença e a exaltação de elementos grotescos na estética barroca, tais como o gosto pelo contraste, pelo heterogêneo, pela metamorfose ou inconstância (referência a Proteu), pela ostentação, simbolizada na figura do pavão, e a acentuada afetação, que pelo forte uso de máscaras, também denota ambigüidade e dissimulação (Cf. ROUSSET, 1954). As mascaradas e as pastorais do barroco têm como cenário o modelo dos jardins italianos do Renascimento, decorado com grutas, rochedos e cascalhos, passando a ilusão de primitivismo. Na construção deste cenário barroco é retomada a noção de gruta como um teatro original, obra de arte da natureza (como nas grutas de Boboli), assim, a encenação de peças neste tipo de cenário corresponderia a uma mise en abyme de um teatro dentro do outro, cara ao barroco.

\footnotetext{
${ }^{2}$ No que concerne à problemática origem das máscaras (carnaval de Veneza, Antigüidade grega e egípcia), vale ressaltar a consideração tecida por Georges Bataille, em Les larmes d'Éros (1961), ao associar o nascimento da arte às ilustrações pré-históricas encontradas em cavernas. Ao analisar um desenho encontrado na gruta de Lascaux, Bataille destaca a caracterização do personagem principal, um homem representado com uma cabeça de pássaro, tendo a face alongada por um bico. O escritor sustenta que a paramentação humana com traços animalescos remonta a hábitos e crenças do homem primitivo, constituindo um enigma para o homem moderno, visto as diferentes fases de evolução e os milhares de séculos que os separam.
} 


\section{Revista InterteXto / ISSN: 1981-0601}

v. 9 , n. 1 (2016)

Em oposição à fortuna do grotesco no século XVII francês, na Alemanha, o termo era utilizado apenas como substantivo, designando certo tipo ornamental. Considerandose que o termo grotesco e os vocábulos correspondentes em outras línguas são empréstimos do italiano, é evidente que, para os franceses dos séculos XVI e XVII, o vocábulo não representava um estrangeirismo na mesma proporção em que o era para os alemães. Assim, seria errôneo atribuir uma propensão dos franceses e dos espanhóis ao grotesco, como se fez durante algum tempo.

Apenas no século XVIII, o conceito de grotesco será desenvolvido na Alemanha, através do trabalho de artistas como Möser, Hoffmann, Jean Paul e Gœthe. Estes artistas retomaram as significações atribuídas ao grotesco de Rafael a Callot (sogni dei pittori, absurdo, híbrido), dotando-as, porém, de um conteúdo mais profundo e trágico. Os alemães enriquecem o conceito de grotesco através da correlação desta estética com as pinturas do holandês Pieter Brueghel, o Velho (1525/30 - 1569) que, para eles, seria um dos seus mais legítimos representantes. Brueghel inicia sua carreira na esteira das criações fantásticas e horrorosas de Hieronymus Bosch (1450 - 1516). Este pintou retábulos com cenas do inferno e do Apocalipse bíblico, dando vida a um mundo alheado, onde seres espectrais e quiméricos, com base na ordem divina, atuariam como punidores ou tentadores. Brueghel opera transformações significativas com relação à obra de seu precursor, se distanciando do recinto eclesial e fazendo irromper o diabólico em nosso mundo familiar, que teria todas as suas ordenações rompidas. A Tentação de Santo Antão (1555-1558) também foi representada por Brueghel, considerado o maior nome da escola primitiva do grotesco diabólico, com um estilo mais extravagante e menos refinado que o de Jacques Callot. Ao lado das cenas infernais e monstruosas criadas por Pieter Brueghel figura uma série de gravuras que datam de 1558 e que representam, de maneira fantástica, as Virtudes e os Vícios. Segundo T. Wright "da composição de personagens fabricados com partes de animais, esta escola primitiva de grotesco passou à criação de personagens animados feitos com objetos inanimados, tais como máquinas, instrumentos de diferentes espécies, utensílios de cozinha" (1875, p. 267). Assim, os artistas alemães do século XVIII recorrem a Brueghel para tecer interpretações lúgubres do grotesco, de forma que os ornamentos de Rafael, por exemplo, perdem seu traço leve e lúdico para, como os monstros criados por Brueghel, indicarem o absurdo, o non-sense. O demônio do grotesco alemão guarda semelhanças com o de Brueghel, denotando horror, contra- 


\section{Revista InterteXto / ISSN: 1981-0601 \\ v. 9, n. 1 (2016)}

senso e tormento, e não com aquele que, durante o século XVII, fora transformado em personagem de farsas. Justus Möser (Arlequim ou Defesa do Grotesco-Cômico - 1761), E.T.A. Hoffmann (Fantasias ao Estilo de Callot - 1814) e Jean Paul (que acrescentou um prefácio especial à obra de Hoffmann) situam o ilustrador da Commedia de Il'arte ao lado de Brueghel no que concerne ao gênero grotesco caracterizado por um fantasiar horroroso. As ilustrações de Callot apontariam para um conflito entre o humano e o animalesco, assim como para relações secretas entre estes domínios, dando origem a seres fantásticos que viriam de um mundo escondido pelo véu do burlesco. O objetivo destes artistas consiste em rasgar esse véu, pondo em evidência o sentido nefasto e angustiante presente nas ilustrações, caricaturas e esboços de Jacques Callot. Tal postura corresponde a uma reflexão construída por Henri Bergson, no livro O riso $\left(1^{\mathrm{a}}\right.$ edição de 1859): "a arte do caricaturista [...] tem algo de diabólico, reergue o demônio que o anjo subjugara" (2004, p. 19-20). Dentre os tipos fixos da Commedia dell'arte, verifica-se que a preferência dos alemães recai sobre Arlequim, personagem que dispõe de características que remetem a uma significação nefasta. Segundo Bernard Jolibert, a etimologia do nome de Arlequim pode ser associada a "Erlkönig, pequeno demônio das lendas nórdicas, (ao) diabo Alichino, da Divina Comédia de Dante (XXI e XXII), (a) Erlequin, das antigas lendas populares francesas" (1999, p. 20). Esta relação ao demoníaco é acrescida de um componente lúgubre e angustiante, simbolizado pela máscara negra que encobre a face de Arlequim. A composição grotesca do personagem é complementada pelas formas assimétricas e multicoloridas dos retalhos que formam a sua vestimenta e por uma touca paramentada com um rabo de raposa, acessório que desde a Idade Média é utilizado para tecer alusões irônicas e sarcásticas ao alto clero, à moral religiosa. De acordo com Wolfgang Kayser, o teatro do Sturm und Drang também conta com vários traços do grotesco, sobretudo no que se refere ao mundo quimérico da Commedia de Il'arte e seu excêntrico estilo de movimento. Além deste tipo característico de movimentação, constata-se, por volta de 1770, uma acentuada tendência dos artistas germânicos a converter os personagens da Commedia dell'arte em bonecos articulados do teatro de títeres. Esta conversão do organicamente animado para o mecanicamente animado é classificada como grotesca pelo fato de tornar estranho o nosso mundo, numa mistura de realidade e ficção. Neste período do pré-romantismo alemão, em Satyros (1773), Gœthe dá vida a um protagonista essencialmente grotesco, um monstro construído numa mistura de homem e carneiro. 


\section{Revista InterteXto / ISSN: 1981-0601}

v. 9 , n. 1 (2016)

A plasmação de um grotesco infernal e abismal, privilegiada por holandeses e alemães, encontra ainda um representante espanhol, Francisco Goya, cuja produção artística, que se inicia no século XVIII e se estende até o século XIX, apresenta grande relevância na trajetória da estética grotesca. Goya se opõe à busca pelo belo empreendida pelos neoclássicos, dando destaque ao princípio tenebroso, ao mal, ao sofrimento e ao desgaste da matéria, enquanto elementos integrantes da realidade humana, assim, segundo o pintor espanhol, a representação de um universo completo deve contar com um espaço para a manifestação do grotesco, das sombras e da violência. A obra de Goya pode ser subdividida em duas fases: um momento inicial, de natureza mais contida, onde o elemento inquietante e estranho aparece velado pela harmonia, graça e leveza das formas que o circundam, como se constata em 0 jogo da cabra-cega e em o manequim, quadros que ilustram o encobrimento de uma cena de suplício por meio de uma aparência lúdica. Jean Starobinski compara o estilo inicial de Goya ao de outro grande pintor da época, sustentando que "como diante de Fragonard, por vezes ficamos obsedados pela idéia do avesso negro daquilo que se oferece na opulência luminosa da vida sensível" (STAROBINSKI, 1988, p. 122). A partir de 17921793, época onde Goya enfrenta a doença que o deixará surdo, se configura o segundo momento de sua produção artística, marcado por um afloramento das sombras, do grotesco monstruoso e de cenas sangrentas. Denunciando a perversão da razão, do culto das luzes e do mito solar da Revolução, que substitui o mito solar da monarquia, Francisco Goya assume um estilo pessimista e desiludido fundamentado na atmosfera de trevas e de terror que sobreveio ao ano de 1789, traindo as expectativas de progresso e de liberdade. A série de ilustrações dos Caprichos (1793-1798) e dos Desastres da Guerra (1810-1815) representam a inversão do princípio das luzes, a racionalidade demente que legaliza a violência, o horror e o sofrimento decorrentes dos ideais de glória e das conquistas napoleônicas, constituindo o que Jean Starobinski qualifica como "a potência anárquica de negação que não se teria manifestado se o imperativo da ordem diurna não houvesse sido promulgado" (1988, p. 127). Wolfgang Kayser analisa uma das estampas do ciclo dos Desastres da Guerra, intitulada Contra o bem público, onde uma criatura dotada de garras, patas e asas de morcego no lugar das orelhas, assumindo a função de jurisconsulto, aparece sentada numa cadeira, fazendo anotações num grande livro. A atividade humana desenvolvida pelo personagem contrasta com sua natureza 


\section{Revista InterteXto / ISSN: 1981-0601}

v. 9, n. 1 (2016)

monstruosa. A presença de outros personagens que complementam essa estampa indica a possibilidade de irrupção do demoníaco, de seres noturnos e abismais em nossa realidade, mesclando dois planos distintos, como evidencia a análise de Kayser: "no ângulo direito da gravura, grita e se contorce o desespero das vítimas da guerra - é o nosso mundo em que o monstro horripilante ocupa seu lugar dominante" (2003, p. 14-15).

No Grande Século francês, o conceito de grotesco sofre um processo de achatamento (repetindo-se o mesmo uso do termo que vigorava no século XVII) e esterilização, provavelmente, devido ao trabalho dos filósofos, o culto da razão e do equilíbrio. No entanto, deve-se destacar que a ornamentação rupestre do estilo rococó, prezado por Luís XV, retoma a associação do grotesco à ambiência rústica criada através de jardins e grutas artificiais. Derivado de rocaille (cascalho), o rococó, ramificação ornamental do barroco, se caracteriza por composições assimétricas, imitando rochedos, conchas, pássaros e vegetais, ou seja, elementos da natureza. Durante o Antigo Regime, a frivolidade e a degradação da nobreza encontra no ambiente das grutas, relacionadas aos deuses do amor, Vênus e Eros, um cenário propício para o culto da libertinagem. A literatura erótica do século XVIII, gênero que circulava sous le manteau (às escondidas), retrata este modismo ao associar cenas de sexo ao espaço das grutas artificiais, que adquirem uma sorte de encantamento erótico, responsável por desencadear a mecânica do desejo. Em Point de lendemain (romance publicado em 1777, mas a versão mais conhecida é a reedição de 1812, que sofreu algumas modificações), de Vivant Denon, verifica-se esta relação entre gruta e erotismo, através da descrição construída pelo jovem personagem, seduzido por uma mulher experiente em orgias, ao entrar no gabinete que acolherá tórridas cenas de paixão. A atmosfera licenciosa e mágica do cômodo, que contava com espelhos, iluminação frágil, aromas de incenso e, até mesmo, um pequeno bosque suspenso, transformando-se num templo do prazer, é descrita pelo jovem embevecido nos seguintes termos:

[...] O lado por onde nós entramos representava pórticos de treliça ornado com flores e ramadas em cada vão; de um outro lado, via-se a estátua de Eros distribuindo coroas; diante desta estátua havia um altar, sobre o qual brilhava uma chama; embaixo deste altar estavam um cálice, coroas e guirlandas; um templo de uma arquitetura frívola acabava de ornar este lado: em frente, havia uma gruta sombria; o deus do mistério guardava a entrada: o assoalho, coberto com um tapete felpudo, imitava a relva. No teto, gnomos suspendiam guirlandas; e do lado que correspondia aos pórticos havia um dossel, sob o qual se acumulava uma quantidade de almofadas, com um baldaquim suspenso por cupidos. [...] ela se aproximou da gruta. Mal atravessamos a entrada, eu não sei que impulso, 


\section{Revista InterteXto / ISSN: 1981-0601 \\ v. 9 , n. 1 (2016)}

habilmente administrado, nos envolveu. Levados pelo mesmo movimento, nós caímos languidamente sobre um monte de almofadas. [...] (DENON, 2000, p. 24-25, tradução nossa)

Nesta linha erótica, deve-se também destacar a obra de Sade, atentando, porém, para a presença de um grotesco satânico e escatológico que permeia os escritos do marquês, configurando outra modalidade de erotismo. Além dos elementos nauseabundos, das cenas de violência, assassinato e tortura, encontra-se na obra de Sade, assim como em Thérèse philosophe (1748, anônimo), Anti-Justine (1798), de Restif De la Bretonne, e Le sopha (1742), de Crébillon Fils, livros fundamentais da literatura filosófica do Grande Século, a presença de personagens velhos e impotentes, de mulheres arruinadas e desfiguradas por uma vida de prostituição de ou libertinagem, denotando o processo de metamorfose, caro ao grotesco, relacionado à usura dos seres.

Ainda no século XVIII, um outro gênero literário na França, o roman noir, baseado no modelo do romance gótico inglês, apresenta em sua estrutura traços do grotesco monstruoso, satânico, erótico e escatológico, relacionado a zonas de representação obscuras e censuradas. O subterrâneo, lugar misterioso e propício às manifestações sobrenaturais, até então relacionado apenas ao espaço de grutas e cavernas, encontra equivalente no ambiente lúgubre e fétido de prisões e calabouços. Este gênero literário se configura pela representação de um horror extremo, de forma que a saturação das sombras e a intensidade antinatural da perversidade dos personagens acabam por propiciar a correlação com uma estética grotesca de cunho satânico e fantástico, como ressalta Max Milner: "Nesta literatura o diabo tem um papel importante. Não somente ele conduz o jogo [...] mas também, [...] ele modela à sua semelhança o caráter do herói cuja tenebrosidade, crueldade e inteligência ultrapassam bastante as possibilidades humanas" (MILNER, 1960, p. 171, tradução nossa).

Na França do século XIX, Victor Hugo consolidará a importância do grotesco no campo artístico, transformando-o num elemento-chave da arte romântica. Pode-se afirmar que com a oposição do grotesco ao sublime, ilustrada no prefácio de Cromwell (1827), Hugo efetivou a legitimação do grotesco enquanto categoria estética. No referido prefácio, o "mestre dos românticos" declara que "o grotesco tem um papel imenso. Ele está em toda parte; de um lado, cria o disforme e o horrível; de outro, o cômico e o bufão" (HUGO, 1968, p. 71, tradução nossa). Segundo Hugo, a natureza multiforme do grotesco seria mais atraente do que a unicidade do belo. A mistura do grotesco e do sublime num 


\section{Revista InterteXto / ISSN: 1981-0601 \\ v. 9 , n. 1 (2016)}

gênero literário é justificada pela afirmação de que o grotesco seria responsável por realçar os elementos sublimes por meio do contraste. É curioso que, apesar de reconhecer a vertente cômica do grotesco, Victor Hugo põe em evidência seu caráter horripilante e monstruoso, acumulando exemplos de deformidade que remontam à Antigüidade, como a hidra, as harpias, os ciclopes e as Eumênides gregas. Torna-se claro que a definição de grotesco proposta por Hugo foi elaborada sob uma vasta influência germânica, de onde se podem destacar: as reflexões de Schlegel em Conversação sobre a poesia (1800); a aniquilação do mundo pelo humor satânico, defendida por Jean Paul; os Contos da noite (1817), de Hoffmann, caracterizado por elementos fantásticos ou sobrenaturais, pelo terror do roman noir e relacionado também ao gênero de pintura conhecido como "quadro noturno", que tem como representantes Caravaggio e Füssli.

No século XIX francês, marcado pelo desenvolvimento da imprensa, surge a chamada "literatura industrial" que promoveu a fortuna da narrativa popular e, através dos monstros e outros elementos sobrenaturais dos contos fantásticos, o grotesco alcançou forte expansão. O pessimismo e o spleen, que marcaram, principalmente, a geração dos pequenos românticos, configuraram um grotesco satírico fundamentado numa postura indiferente face à realidade. $\mathrm{O}$ topos do theatrum mundi, caro ao barroco, é retomado e a vida, sob um olhar frio, é associada a um teatro de marionetes, caricato e sem sentido. Apesar do tom pessimista, a comicidade, embora reduzida, nesta manifestação do grotesco reside "[...] na ilusão de vida e (n)a sensação nítida de arranjo mecânico" (2004, p; 51), segundo as palavras de Henri Bergson. Vale assinalar o sucesso dos personagens e do estilo teatral da Commedia dell'arte na França do século XIX, visto que, em 1816, é fundado o Théâtre des Funambules, gênero popular, caracterizado pela pantomima, acrobacias e malabarismos. A habilidade e a genialidade de Jean-Gaspard-Baptiste Debureau, intérprete do novo Pierrot, conquistaram a admiração de grandes nomes da literatura e da crítica, tais como "Jules Janin, autor de um Debureau tão requintado quanto fantasioso, Théophile Gautier, Charles Nodier, que escreveu uma pantomima para ele, George Sand, que o recebeu em sua casa" (ATTINGER, 1950, p. 438, tradução nossa). A fama de Debureau e o apoio destes escritores contribuíram para consolidar a fortuna deste tipo de teatro durante a primeira metade do século XIX, atraindo espectadores de diferentes níveis socioeconômicos e promovendo uma mistura de classes na plateia. As apresentações do Théâtre des Funambules se realizavam no Boulevard du Temple que, a partir de 1825, passou a ser conhecido como Boulevard du Crime, devido à natureza 


\section{Revista InterteXto / ISSN: 1981-0601 \\ v. 9 , n. 1 (2016)}

sombria e violenta dos melodramas ali encenados a cada noite, pondo em destaque as mais variadas formas de atentado à virtude.

Em 1844, Théophile Gautier, um pequeno romântico, publica Les Grotesques, opondo-se à regularidade e à sobriedade do regime literário exaltado pelos defensores da arte clássica e sustentando o valor estético do bizarro e do grotesco. Neste livro, Gautier rende homenagem a poetas barrocos marginais, declarando que na obra destes artistas considerados "menores" pode ser encontrado e apreciado "tudo o que os aristocratas da arte não se dignaram a pôr em prática: o grotesco, o extravagante, o trivial, o ignóbil, o chiste ousado, o termo forjado, o provérbio popular, a metáfora hidrópica, enfim todo o mau gosto com sua fortuna" (GAUTIER, 1859, p. 2, tradução nossa). Assim como Hugo, que considera Scarron um dos maiores nomes do grotesco, Gautier busca a legitimação da estética grotesca em sua associação com o barroco.

Esta complexa trajetória do grotesco ao longo dos séculos suscita a relevância do caráter semântico na utilização da língua. Como defende Reinhart Keselleck, a formulação de um conceito associa-se ao caráter pragmático da língua, referindo-se a uma situação concreta que é única. Porém, uma história dos conceitos encontraria fundamentação em estruturas profundas de continuidade semântica, dado que toda sincronia contém uma diacronia presente na semântica, indicando temporalidades que não podemos alterar. No período que compreende a sua descoberta no século XV até o desenvolvimento do romantismo, mesmo sofrendo alterações de acordo com a cultura dos diferentes países onde se manifestou, o grotesco sempre se relacionou a um jogo de deformações e de subversão das leis estéticas, originando formas híbridas, ambíguas, que violavam os limites da razão.

\section{Kayser versus Bakhtine}

Para finalizar a análise da estrutura da estética grotesca será problematizada sua cisão em duas categorias: o grotesco fantástico, com seu mundo onírico, diabólico e sobrenatural, e o grotesco satírico, com seu mundo de máscaras, suas formas caricaturais e afetadas. Esta cisão do grotesco corresponde às divergências interpretativas entre Wolgang Kayser e Mikhail Bakhtine. O primeiro eleva o grotesco romântico, marcado pelo sarcasmo, pelo pessimismo e pela ironia, à categoria de representante por excelência desta estética, afirmando que "como fenômeno puro, o 


\section{Revista InterteXto / ISSN: 1981-0601 \\ v. 9 , n. 1 (2016)}

grotesco se distingue claramente da caricatura chistosa ou da sátira tendenciosa, por mais amplas que sejam as transições e por fundadas que sejam as dúvidas em cada caso" (KAYSER, 2003, p. 40). O segundo defende a teoria de que a verdadeira essência do grotesco estaria associada à alegria das festas populares da Idade Média e do Renascimento. Segundo Bakhtine, o grotesco encontraria a sua mais legítima tradução na festa de carnaval dessas épocas, por sua natureza libertária que proporcionaria uma suspensão temporária de regras, privilégios, hierarquias e tabus. Como na ornamêntica grotesca, constata-se nessas festas populares um processo de inversão da ordem oficial. A associação do grotesco à Commedia de Il'arte é classificada como um vestígio de sua relação com as festas populares, visto que o carnaval deu origem ao mundo quimérico do qual faz parte Arlequim. As máscaras com traços animalescos traduziriam o desejo humano de "trocar de pele" e seriam responsáveis por instaurar um distanciamento que autorizaria o riso. Em seu livro sobre a obra de François Rabelais, Mikhaïl Bakhtine atribui ao grotesco romântico uma unilateralidade responsável por empobrecer a natureza múltipla da estética grotesca. O autor toma como exemplo a diferença da significação da máscara nas duas vertentes, conforme mostra a passagem a seguir:

[...] No romantismo, a máscara perde quase totalmente o seu aspecto regenerador e renovador, adquirindo uma nuança lúgubre. Ela frequentemente dissimula um vazio assustador [...] Enquanto que, no grotesco popular, a máscara sempre encobre o inesgotável caráter da vida, suas múltiplas faces (BAKHTINE, 1970, p. 49, tradução nossa).

Acentuando a importância de uma das vertentes do grotesco, Kayser e Bakhtine elaboram conceitos distintos dessa estética. O primeiro enfatiza a vertente trágica ou romântica, onde o riso aparece como sintoma do medo, da impotência e do desespero dos homens diante dos seres sobrenaturais que se apresentariam em nosso mundo, ou como uma explosão irônica face a um mundo transformado numa "tragédia de marionetes". O segundo insiste na importância do carnaval e da cultura popular e, priorizando a vertente cômica ou popular, qualifica o riso leve e despreocupado como um dos traços principais do grotesco. Para Bakhtine, o grotesco teria por função transformar tudo o que existe de horrível e assustador em nosso mundo, em algo inofensivo e agradável, como uma paródia da realidade, assim, a alegria, mesmo que ela se encontre reduzida ao mínimo, como no caso da categoria romântica, é classificada como um elemento capital na configuração da estética grotesca. 


\section{Revista InterteXto / ISSN: 1981-0601 \\ v. 9 , n. 1 (2016)}

O ponto em comum entre estas teorias, aparentemente divergentes, consiste na atribuição de uma natureza subversiva ao grotesco, seja ela indicada por meio de seus traços horripilantes ou satíricos. Porém, no que concerne à ambiguidade e à tensão, inerentes ao grotesco, os dois autores se posicionam de forma incoerente, dado que ambos desconsideram, ou não atribuem a devida importância, a uma das maiores propriedades do grotesco, responsável por mantê-lo, ainda hoje, sob a classificação de estranho domínio: sua resistência quanto a uma única possibilidade de definição. Pode-se afirmar que a grande "chave" da estética grotesca reside num jogo com o absurdo, pondo em questão os limites da lógica pré-estabelecida, de forma que a mescla de comicidade e de tragicidade deve ser admitida como uma das principais manifestações de seu caráter irresoluto. Desta forma, ainda se deve recorrer ao prefácio de Cromwell para que se obtenha uma definição justa do grotesco, uma vez que Victor Hugo assinala e defende a relação de cooperação entre elementos trágicos e cômicos na composição desta estética, traduzindo, fiel e magistralmente, sua natureza hesitante.

Após a análise da genealogia do termo grotesco, abordando fatores lingüísticos e extralingüísticos que determinaram sua conceituação, e da expansão do vocábulo no campo artístico, do século XV ao século XIX, em diferentes países, torna-se possível depreender e elencar a temática que compõe este complexo e vasto domínio. As noções de metamorfose, inconstância, hibridismo, a oposição ser-parecer apresentam uma constante nas múltiplas manifestações do grotesco. A metamorfose associa-se aos monstros do gênero fantástico, à degradação dos corpos na literatura erótica, e encontra na morte, no processo de putrefação da matéria, seu representante por excelência. 0 hibridismo está presente nos ornamentos descobertos em Roma, no século XV, assim como nas representações artísticas ilustrando o pensamento transformista do século XVI, nas ilustrações de Jacques Callot, de Brueghel, de Goya, e nos personagens de natureza mutante que integram o universo da literatura, desde os sátiros e centauros das obras gregas até os bufões e anões do drama romântico. Além da mistura dos reinos da natureza, o hibridismo também concerne à estética do claro-escuro e às formas heterogêneas e paradoxais do barroco e do romantismo. A inconstância aparece como elemento constitutivo das noções de metamorfose e hibridismo, dando conta de formas flutuantes e de natureza proteiforme. A oposição ser-parecer está relacionada à teatralidade, às marionetes, ao uso de máscaras e maquiagem que denota artificialidade, duplicidade e dissimulação. Com base nesta temática é possível entrever a natureza 


\section{Revista InterteXto / ISSN: 1981-0601}

v. 9 , n. 1 (2016)

complexa da estética grotesca: oposição a todo racionalismo, ordenação e visão equilibrada do real, configuração de um mundo alheado ou desencantado, um jogo com o absurdo e com o demoníaco, numa tentativa de dominá-lo ou expurgá-lo.

\section{Referências}

ATTINGER, Gustave. L'esprit de la Commedia dell'arte dans le théâtre français. Paris: Librairie Théâtrale, 1950.

BAKHTINE, Mikhaïl. L'œuvre de François Rabelais et la culture populaire au Moyen Age et sous la Renaissance. Paris: Gallimard, 1970.

BATAILLE, Georges. Les larmes d'Éros. Paris: Jean-Jacques Pauvert, 1971.

BERGSON, Henri. O riso; Ensaio sobre a Significação da Comicidade. São Paulo: Martins Fontes, 2004.

CAIRUS, Henrique. Coluna "Letras Clássicas" 0002 - Etimologias. In: Blocos Online. Portal de Literatura e cultura, setembro de 2004. Disponível em: http://www.blocosonline.com.br. Acesso em: novembro de 2008.

DARNTON, Robert. Boemia literária e revolução; o submundo das letras no Antigo Regime. São Paulo: Companhia das Letras, 1989.

DENON, Vivant. Point de lendemain: roman érotique. Paris: Librio, 2000.

GAUTIER, Théophile. Les Grotesques. Paris: M. Levy, 1859.

HUGO, Victor. Cromwell. Paris: Flammarion, 1968.

JEANNERET, Michel. Perpetuum mobile. Métamorphoses des corps et des œuvres de Vinci à Montaigne. Paris: Macula, sd. .

JOLIBERT, Bernard. La commedia dell'arte et son influence en France $d u X V I^{e}$ au XVIII siècle. Paris: L'Harmattan, 1999.

KAYSER, Wolfgang. O grotesco. São Paulo: Ed. Perspectiva, 2003. 


\section{Revista InterteXto / ISSN: 1981-0601}

v. 9 , n. 1 (2016)

KOSELLECK, Reinhart. "Uma história dos conceitos”. In: Estudos Históricos, vol. 5, n. 10. Rio de Janeiro: 1992, p. 134-146.

MILNER, Max. Le diable dans la littérature française. De Cazotte à Baudelaire. 17721861. Paris: José Corti, t. I, 1960.

ROUSSET, Jean. La littérature de l'âge baroque en France. Paris: José Corti, 1954.

STAROBINSKI, Jean. 1789: Os emblemas da razão. Trad. Maria Lúcia Machado. São Paulo: Companhia das Letras, 1988.

WRIGHT, Thomas. Histoire de la caricature et du grotesque dans la littérature te dans l'art. $2^{\mathrm{e}}$ éd. Trad. d'Octave Sachot. Paris: Adolphe Delahays, 1875. Disponível em: http://gallica.bnf.fr. Acesso em: maio de 2006.

Artigo recebido em 02/02/2016

Artigo aceito em 16/03/2016 